\title{
Belgeo
}

Revue belge de géographie

$1 \mid 2017$

Miscellaneous

\section{Using contact potential measurements to analyse future intercity links made possible by the Tours- Bordeaux High-Speed Rail line}

Utilisation de l'indicateur potentiel de contact dans l'analyse de l'impact de la ligne TGV Tours-Bordeaux sur les liaisons entre villes

\section{Alain L'Hostis, Liu Liu and Thomas Leysens}

\section{OpenEdition}

\section{Journals}

\section{Electronic version}

URL: http://journals.openedition.org/belgeo/19584

DOI: 10.4000/belgeo.19584

ISSN: 2294-9135

\section{Publisher:}

National Committee of Geography of Belgium, Société Royale Belge de Géographie

\section{Electronic reference}

Alain L'Hostis, Liu Liu and Thomas Leysens, « Using contact potential measurements to analyse future intercity links made possible by the Tours-Bordeaux High-Speed Rail line», Belgeo [Online], 1 | 2017, Online since 25 July 2017, connection on 30 April 2019. URL : http://journals.openedition.org/ belgeo/19584; DOl : 10.4000/belgeo.19584

This text was automatically generated on 30 April 2019

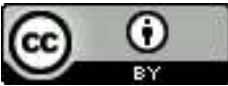

Belgeo est mis à disposition selon les termes de la licence Creative Commons Attribution 4.0 International. 


\section{Using contact potential} measurements to analyse future intercity links made possible by the Tours-Bordeaux High-Speed Rail

\section{line}

Utilisation de l'indicateur potentiel de contact dans l'analyse de l'impact de la

ligne TGV Tours-Bordeaux sur les liaisons entre villes

Alain L'Hostis, Liu Liu and Thomas Leysens

\section{Introduction}

1 The purpose of transport projects that bring about modifications in transport supply, for example new high-speed rail lines, is to improve travel links between cities and regions. High-speed rail projects offer new links that compete with existing fast and efficient transport systems, especially air transport, complicating the global transport supply balance (Armstrong, 1998).

2 The cost, objectives and complexity of these projects explain why their economic and territorial dimensions require multiple assessments. Most of the literature on high-speed rail projects has focused on general economic assessment (Bonnafous, 1987; Givoni, 2006; Campos and de Rus, 2009), their impact on regional labour markets (Haynes, 1997), and specifically on the issue of the impact on accessibility (Gutierrez, 2001; Levinson, 2012; Shaw et al., 2014). From the perspective of territorial analysis, accessibility is the main indicator because it relates the key parameters of the transport system to a spatial analysis of its spatio-temporal performance and of the opportunities for interaction it creates (Geurs and van Wee, 2004). In this domain, high-speed rail's contribution to territorial cohesion, inspired by European territorial policy goals, is an emerging topic in 
the literature (L'Hostis and Baptiste, 2006; Bröcker, Korzhenevych, and Schürmann, 2010; Ortega, López, and Monzón, 2012), which seeks to analyse not just the magnitude, but also the spatial distribution of the effects.

Within the timescale of the current period of the development of high-speed rail supply, a literature review shows the trends in policy priorities and academic knowledge. In both domains it is increasingly recognised that, in terms of territorial development, cities are seen as focal points for economic development (Sassen, 1991; Veltz, 1997; Le Galès, 2003; Halbert, Cicille, and Rozenblat, 2013). This has shifted attention to the accessibility of cities as a basis for the assessment of high-speed rail projects. It is this aspect, where the literature review shows a clear need for development, that we intend to investigate. Our intention is to pursue these analyses of high-speed rail from a territorial assessment perspective, at the crossover between the analysis of accessibility and of urban development potential. In this article, we propose an in-depth measurement of the effects of transport system projects, in a multimodal context, by focusing on cities and on the primary exchange needs of economic systems.

In this context, a literature review shows that no extensive analysis of the impact of contact potential (Erlandsson, 1979) has been conducted on the territorial side, despite its relevance as an indicator; the purpose of this paper is to fill this gap by applying a contact potential analysis to a new high-speed rail project.

5 In this article, the contact potential indicator is implemented in a European context and mapped to produce an analysis in two distinct fields: indications about the territorial organisation of a network of cities, and indications about the connectivity of high-speed transport networks, both rail and air. The indicator is tested in the context of the opening of a new section of high-speed rail between Tours and Bordeaux. The Tours-Bordeaux case has been chosen because the spatial distribution of cities in this area follows a very specific pattern, with a dense cluster in the Loire valley area on the one hand, and on the other hand a sparse hinterland around Bordeaux. Combined with the fact that the extension of the high-speed rail network is currently underway, these factors make intercity contact potential in this region a complex issue that demands investigation.

\section{Metropolises and business travel}

We start this section on metropolises and business travel by discussing a number of approaches in geography and economics that have explored the topics of mobility between large urban entities. This section considers the literature on metropolises, time geography, Richard Florida's approach and the ideas of sociologists on mobility.

7 Metropolitanisation, or global city formation ${ }^{1}$, defined as the emergence of large urban entities able to communicate with their counterparts at national, continental or global scales, is associated with the most recent manifestations of globalisation (Veltz, 1997). Long-distance communications and exchanges are key contributors to these economic dynamics. In the analysis of regional development, transport and communications are often treated as key components, though the causal link between transport infrastructure and economic development has been challenged (Offner, 1993).

8 If we consider metropolises as urban entities that maintain exchanges across long distances, air travel represents the main means of transport for individuals (Sassen, 1991; Haggett, 2001). Airport infrastructures, the number of outgoing or incoming flights, the 
number of potential destinations, are among the indicators used to measure the position of cities in the global ranking (Grubesic and Zook, 2007). In addition, metropolises have to communicate with cities and functional spaces within their own hinterland, so need to encompass the full range of transport modes.

The Lund school, which grew out of the work of Hägerstrand (1970), the inventor of timegeography (Chardonnel, 2001), represented a significant new departure in economic geography, proposing explanatory models for spatial development and the spread of innovations. Works produced by the school dealt with the links between hubs within a regional space (Törnqvist, 1973). Within this current, Erlandsson's contribution focuses explicitly on the need for face-to-face interactions between agents of economic development (Erlandsson, 1979), despite the development of long distance communications. In recent times, the need for such interactions has been a core issue in the analysis of productive systems (Torre, 2009). As the literature shows (Kwan, 1998; Dijst, de Jong, and Ritsema van Eck, 2002; Kwan et al., 2003), the analytical framework of time-geography remains relevant to the understanding of urban and regional economic developments.

Many discussions of Florida's creative city relate to the definition of the creative class. According to Vivant, the creative class associates creative people in the advertising, banking and superior sectors, with creative people in the intellectual and artistic professions (Vivant, 2009). The debate focuses on the complex issues of gentrification and rarely examines the need for the long distance exchanges and communications essential to the creative city. To ignore the theoretical and practical implications of this debate would be a mistake. For Vivant (2009), Florida's theory relates to works on the territorial economy in the 1990s, and particularly Sassen's contribution regarding metropolises (1991). Before this, Gottmann had identified the phenomenon of re-agglomeration around the development of superior activities, at that time called the quaternary sector (Gottmann, 1970). Vivant highlights the notion of copresence, where face-to-face is a privileged mode for interactions in creative activities (Vivant, 2009, p. 61). In this approach, the metropolis as a place of copresence represents the environment where an advanced economy can develop. These considerations are also echoed by Simmel's observations of life in metropolises as characterised by a proliferation of sensory stimuli (Simmel, 1903). By contrast with life in rural areas or small towns, the different experience of the modern city changes key components of psychic life (Simmel, 1997, p. 175).

11 In the current organisation of businesses, executive personnel spend up to three-quarters of their working time in meetings, phone calls and discussions, which together account for half the time spent on copresence activities (Boden and Molotch, 1994, p. 272). In the knowledge industry sector, companies want an environment that is rich in interactions, and therefore seek to link up with multi-localised resources and actors via powerful networks (Bathelt, Malmberg, and Maskell, 2004).

12 Having discussed economic and geographical approaches to the relations between metropolises and business travel, we will now consider the transport modes involved and the main characteristics of mobility. In intercity relations, transport modes are required to fulfil specific requirements, notably being fast enough to operate over long distances. Air travel is a key element of any metropolitan strategy, but in a number of parts of the world the rail mode, and more specifically high-speed rail, has been introduced on certain origin-destination pairs like Paris-London, with such success that some authors 
consider the future disappearance of air competition to be a likelihood (Behrens and Pels, 2012). In the literature on high-speed rail, it is considered that three hours represents the maximum feasible travel range for the train (Houée and Klein, 1999), though rail begins to become less competitive than air travel at an even lower level (Dobruszkes, Dehon and Givoni, 2014). Beyond these thresholds, the air mode is considered more efficient. Nevertheless, Bozzani has shown that this threshold can be extended to four hours in particular conditions: for example, in the case of intermediate cities and where there is a shortage of airport transport links (Bozzani-Franc, 2006).

For Klein and Houée, who studied the effects on mobility of the introduction of highspeed rail in western France, the main characteristics of this mode are (Houée and Klein, 1999, p. 151; Albalate and Bel, 2012):

- strong competitiveness of rail compared with air travel,

- a contraction in the length of stays, with a preference for single-day round trips over trips involving overnight stays,

- the development of half-day round trips, and

- an increase in the frequency of trips.

The development of high-speed rail has contributed to making the single-day round trip the norm of business travel (Klein, 2005). In addition, the study of mobility shows that the introduction of high-speed rail has blurred the distinction between ground and air transport. For instance Kellerman, focusing on daily mobilities, distinguishes between ground, air and virtual mobilities (Kellerman, 2012, p. 76). Kellerman contrasts ground and air mobilities by the criterion of speed, and by the type of trips they address. Nevertheless, in time-space terms, high-speed rail is becoming competitive with air, and in certain cases is replacing air travel.

We have now established the connection between metropolises and work-related mobility. We are now in a position to describe the territorial assessment of high-speed rail we wish to conduct, and to this end we will begin by focusing on certain features of metropolitan business travel.

Because businesses are organised into branches and multiple hierarchical structures scattered over vast areas, and because employees are interdependent, companies make intensive use of communications, both internally and externally (Aguilera, 2008). In addition, the increase in communication of all kinds and the expansion of markets are increasing the need for business travel. Information technology is unable to provide the same rich experience as direct face-to-face contact (Aguilera, 2008), since:

- analysis has shown a positive correlation between the frequency of direct contacts and knowledge sharing in a sample of small and medium-sized enterprises in all economic sectors except agrifood (Aguilera and Lethiais, 2011);

- commercial negotiations require direct contact because they involve complex forms of communication (Lian and Denstadli, 2004; Aguilera, 2008);

- direct contact is needed for the transmission of informal information (Lorentzon, 2003) and non-codified knowledge (Bathelt, Malmberg and Maskell, 2004);

- direct contact allows mutual trust to develop, which is a key element in the successful organisation of projects (Gallaud and Torre, 2005; Aguilera, 2008; Wickham and Vecchi, 2009).

17 In addition, when individuals are not separated by long distances, direct contacts will be more frequent and will depend less on the use of information technology or on the 
importance or type of information (basic or complex) to be exchanged (Aguilera, 2008; Aguilera and Lethiais, 2011). In the context of the innovation economy, the need for mobility between metropolises is explained by the need to accumulate - beyond codified knowledge that is easily accessible with little or no direct contact - tacit knowledge that develops through interpersonal relations, both locally and remotely (Bathelt, Malmberg and Maskell, 2004). This soft network of interpersonal relations contributes to the economic performance of cities (Bathelt, Malmberg and Maskell, 2004).

The mobility statistics in France for the year 2010 show that business purposes accounted for one fifth of all long-distance trips. Of these, more than half were one-day business trips, the rest involving one or several nights away (Roussel, 2011). This analysis shows the importance of this type of mobility in the present context of economic development.

\section{Assessing the accessibility of metropolises using the contact potential indicator}

19 The analysis of metropolitan accessibility traditionally uses the criterion of airport passenger levels, as exemplified by Rozenblat and Cicille in their work on European cities (Rozenblat and Cicille, 2003). In the more general framework of the relations between transport and territories, accessibility is one of the most widely used indicators (Conesa and L'Hostis, 2013). Defined as the degree of ease with which one can reach a location to perform an activity, accessibility is used in many studies and official reports and documents produced to support decision-making in the field of spatial policies (Conférence des Régions Périphéries Maritimes, 2002; BBR, 2006). Accessibility is a way of measuring opportunities generated through the combination of transport systems and territories. We propose to develop an approach that is complementary to the usual location-focused accessibility indicators (Spiekermann and Wegener, 2007) by addressing linkages in spatial systems. Our proposal offers a way to assess the possibility of face-toface interaction between individuals located in cities a long distance apart.

The time geography school of geography highlighted the complexity of spatial relations in regional spaces (Engström and Sahlberg, 1973). This analysis describes a number of sets of links characterised by different functions and distances. One of the prominent approaches in time geography is indicators of contact potential, a concept introduced by Törnqvist (Törnqvist, 1970). As Hägerstrand states, economic specialisation has made horizontal linkages and cooperation between separate companies indispensable to the process of production (Törnqvist, 1970).

21 In his 1968 article, Törnqvist relates the issue of contacts to the wider question of the diffusion of innovation, the domain which originally gave rise to time geography (Törnqvist, 1968). It began with early work on epidemics and the spread of technical innovation, both of which require face-to-face interaction. A survey conducted among passengers on Sweden's air transport system in the late 1960s showed that the need for face-to-face interaction is greatest between the administrative units of businesses, defined as the units that "receive, process and communicate" information in productive systems. The spatial separation between different functions within firms and the need for cooperation between businesses increase the necessity of face-to-face interaction involving long-distance transport. At the same time, the expansion and concentration of administrative functions within the biggest cities highlights the development of 
urbanisation. In this context, regional analysis shows that the attractiveness and importance of a particular place or region depend partly on linkages with other cities and regions, and partly on the potential to travel to those distant locations (Erlandsson, 1979).

Törnqvist developed a method for measuring the potential to achieve direct distant contact, which he called contact potential (1970), sometimes referred to as contactability (Haggett, 2001). In order to measure this potential, Törnqvist considered the time available at destination, trip duration and the cost of a one-day return trip. The first analyses were conducted at regional scale, and then extended to national and European scales. Two sub-indicators were proposed for the origin and destination cities. The time criteria were the global duration of trips, which had to take place between 6 a.m. and midnight, and time spent at destination, either 4 or 8 hours. The choice of these figures can be directly related to the daily constraint of the time geography approach and to the minimum time needed to perform activities, in this case a working day and a meeting.

Figure 1. Parameters of the contact potential indicator. return trips with monomodal chains.

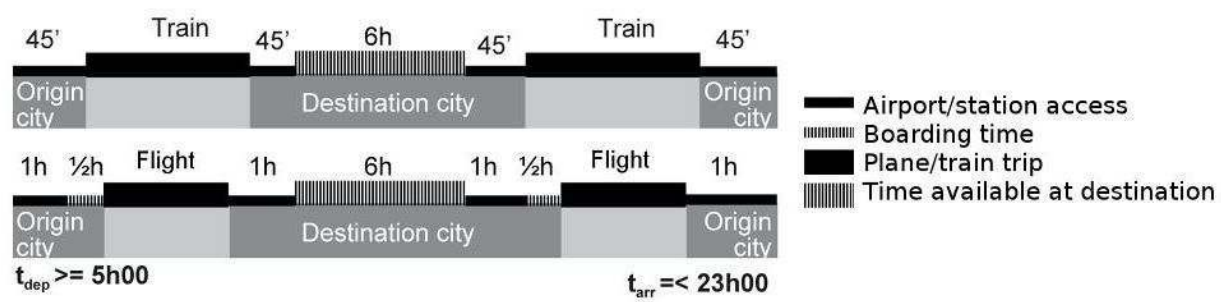

Our aim in this paper is to develop measurements of the quality of existing and future links in urban systems based on the principles of time geography and contact potential. We want to assess the possibility for an individual to take part in a business meeting in a distant city, allowing for her or his personal time patterns. It should be noticed that family constraints, which can be considered in comparable approaches at conurbation scale (Farber et al., 2014), are beyond our scope here because long-distance trips usually lay a heavy time burden on personal time potentially devoted to family. Operators in the air transport sector usually assume a duration of 6 hours at destination in order to judge the accessibility of a distant city ${ }^{2}$. We have identified criteria represented in Figure 1, in which the global daily time pattern ranges from 5 a.m. to 11 p.m. and the time duration available at destination is 6 hours, including access to the transport mode at both ends of the trip. The difference of one hour compared with Törnqvist's criteria was chosen in order to allow for early take-off at European airports. Particular attention is given to the description of transport access sections of long-distance trips. All these parameters have been set in order to allow fair comparison of air and rail transport (Bozzani, 2005). On the basis of all these parameters and a computation of trip duration, the available time at destination is measured by the following formula:

atd $=\mathrm{dtp}-2 \mathrm{t}-2 \mathrm{hsa}-2 \mathrm{dsa}$

atd $=$ available time at destination

$\mathrm{dtp}=$ daily temporal pattern

$\mathrm{t}=$ trip duration by chosen mode

hsa $=$ home to station or airport time

$\mathrm{dsa}=$ destination to station or airport 
Available time at destination (atd) is deducted from the given daily temporal pattern (dtp) and the parameters of the return trip, with trip duration by the main high-speed mode $(\mathrm{t})$ and the duration of the access (hsa) and egress (dsa) trips.

In addition, these parameters have been adjusted with the aim of producing a differential measurement when assessing various European cities. The criteria need to be kept strict. If the criteria are relaxed, for example by reducing the time available at destination, or allowing next-day return, every city becomes accessible, with the result that the indicator ceases to be either selective or useful, and fails to assess the performance of the transport system.

\section{Implementation of a contact potential indicator}

The objective of the Tours-Bordeaux high-speed rail project is to improve overland accessibility in western France. The new $300 \mathrm{~km}$ line will in particular improve links between the Paris-Bordeaux origin-destination pairing, simultaneously reducing congestion and developing freight capacity on the existing rail line, and cutting rail travel time from 3 to 2 hours, making it competitive with air travel on the same route.

Figure 2. Map of French high-speed rail network opened and under construction in mid-2017.

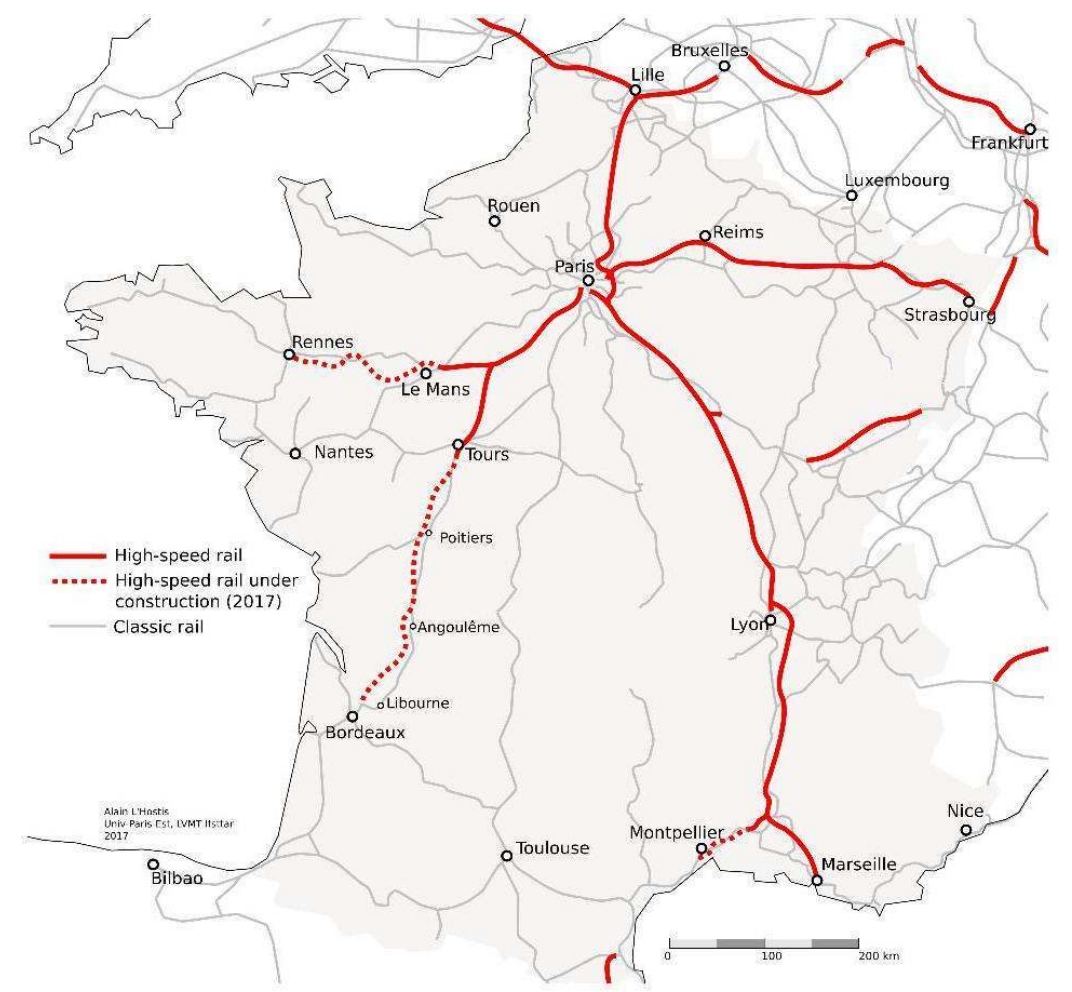

Most approaches to the spatio-temporal performance of transport systems at national or international scale are based on minimum times (Spiekermann et al., 2012, pp. 26-27). We chose to depart from this approach because we wish to analyse air and rail equitably and to take into account the issue of intermodality. We took the view that in the case of schedule-based transport modes, an approach based on timetables was more relevant than the minimum times used in other approaches (Gutiérrez, 2001). Only a timetable 
approach takes account of intermodality and flight and train connections in computing minimum paths.

We collected the timetables for a typical winter day in 2009/2010. The plane schedules were taken from the comprehensive data in the OAG database ${ }^{3}$, while the train schedules were taken from the German railways website ${ }^{4}$, which has the best geographical coverage among equivalent websites. The minimum paths were computed using the Musliw software ${ }^{5}$. The volume of return trips between cities was measured by means of a database of trips computed in Musliw. The list of European cities is based on ESPON databases and includes all agglomerations of more than 200000 inhabitants (Mathis et al., 2004; Lennert et al., 2010). The resulting database is structured to describe the transportation graph. Nodes include transport nodes and cities with geographical coordinates, while each edge is associated to a transport service with hours of departure and arrival and type of mode.

We focus on French cities that are mainly concerned by the modifications of the contact potential due to the Tours-Bordeaux high-speed rail line ${ }^{6}$. A methodological issue concerns the association of cities to transport nodes, railway stations and airports. It must be noticed that in the case of airports serving several cities, like Valenciennes served by Lille-Lesquin, Saint-Nazaire served by Nantes-Atlantique or Mulhouse served by Euroairport, the airport has been attached to the main city served, in these cases Lille, Nantes and Basel respectively. Providing a trip by car can be covered in the access time constraint ( 1 hour to the airport, 45 minutes to the railway station), the contact potential of Lille can then be seen as equivalent to an accessibility level from neighbouring cities. Hence the contact potential of several French cities should be adjusted with cross-border European cities levels not represented in the cartography for legibility reasons.

The reference date is set at 2009 for two reasons. First, because there were no major infrastructure operations during this period, whereas there were disruptions and delays in 2012 caused by major works, with the result that the train journey between Paris and La Rochelle took 2 hours 54 minutes in 2009, but 3 hours 20 minutes in 2012. From the perspective of 2013, the year 2017 was seen as a realistic date for the opening of the new infrastructure and services. 
Figure 3. Principle for the organisation of existing (grey) and new (blue) services.

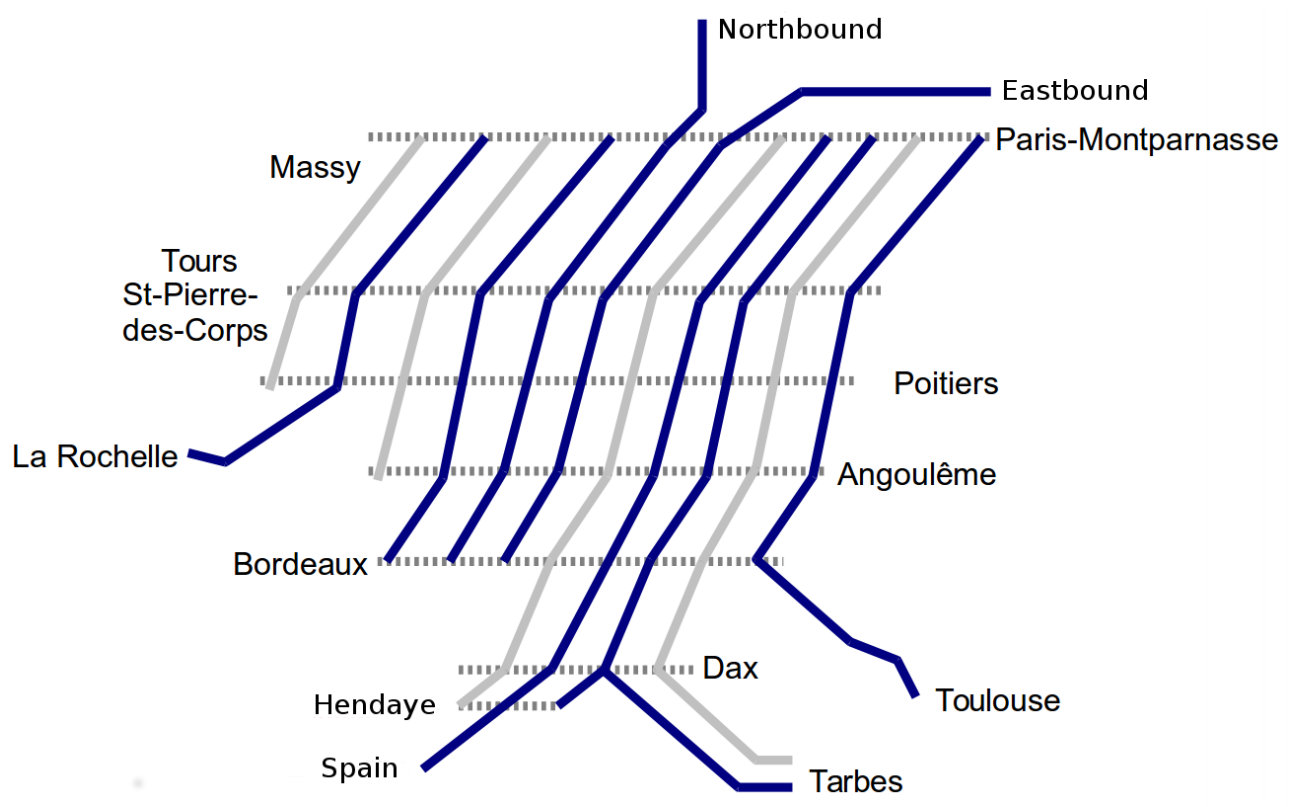

SOURCE: DOSSIER DE COHÉRENCE INTERMODALE

32 Figure 4 below shows the European contact potential of French cities in 2009. The map indicates how many French and European cities can be reached in a single day from each French city. It also shows the contribution of transport modes to the contact potential levels. Contact potential is related to conurbation size: high demand creates high levels of supply and increases the possibility of return trips, whatever the urban density nearby. Bigger cities show a significant contribution from the air mode, whereas the contact potential of many smaller conurbations is based exclusively on rail. Intermodality, i.e. the combination of rail and air in a single trip, plays a role for only two French cities, Orléans and Lille, but this role is significant.

In the region of study, the contact potential of Bordeaux is primarily attributable to air, with rail coming second. 
Figure 4. European contact potential of French cities in 2009.

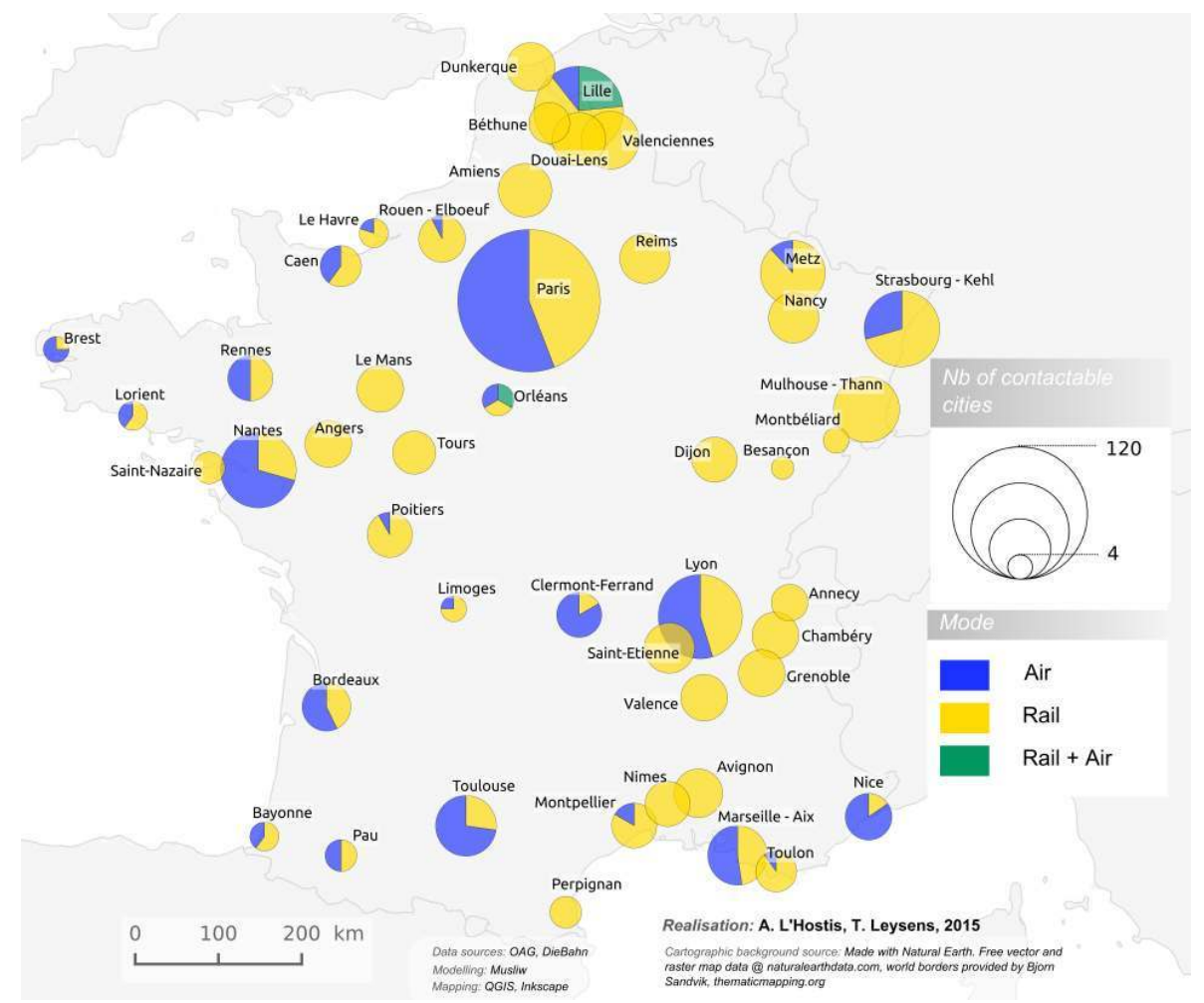

New rail schedules were based on an official document presented during the public inquiry on the Tours-Bordeaux high-speed line. We chose scenario A, which was assessed by experts as the most likely. This scenario foresees thirteen new services from Paris on the line and continuing beyond, and five new services continuing beyond Île-de-France (Paris).

With regard to air connections, we used the services available in 2009. As it was very difficult, at the time of the study, to predict air transport supply in 2017, we chose to take that of 2009 as the basis for this future period. Two opposing factors prompted us to make this choice. First, according to European and global trends, general growth in air transport supply can be expected. Nevertheless, we know from experience that the introduction of high-speed rail services results in a corresponding fall in air transport supply on the same routes. As these two tendencies run counter to each other, it is permissible to assume that air supply remains essentially stable between 2009 and 2017 .

The map below shows the contact potential of cities in 2017 and the new and improved connections made possible by the new high-speed line between Tours and Bordeaux. The size of each circle indicates the number of cities contactable from a given city and the colours refer to transport mode chains. Blue is for air and red is for train, while purple stands for the combination of air and rail in a single journey.

In analysing these results it is important to consider that the contact potential indicator for a given city is related to the size and position of that city within Europe. Size is associated with substantial airports and infrastructures, while position means that the contact potential of a city is closely connected with the local density of cities. By way of illustration, Bordeaux is relatively isolated, lacking linking cities in its neighbourhood, and therefore develops contact potential with remote cities, whereas Angers is located in 
the middle of a rich city network along the Loire Valley, and exhibits nearly equal contact potential with Bordeaux despite its much smaller population.

Figure 5. European contact potential of French cities in 2017 and new and improved relations with the opening of the new high-speed Tours-Bordeaux rail line.

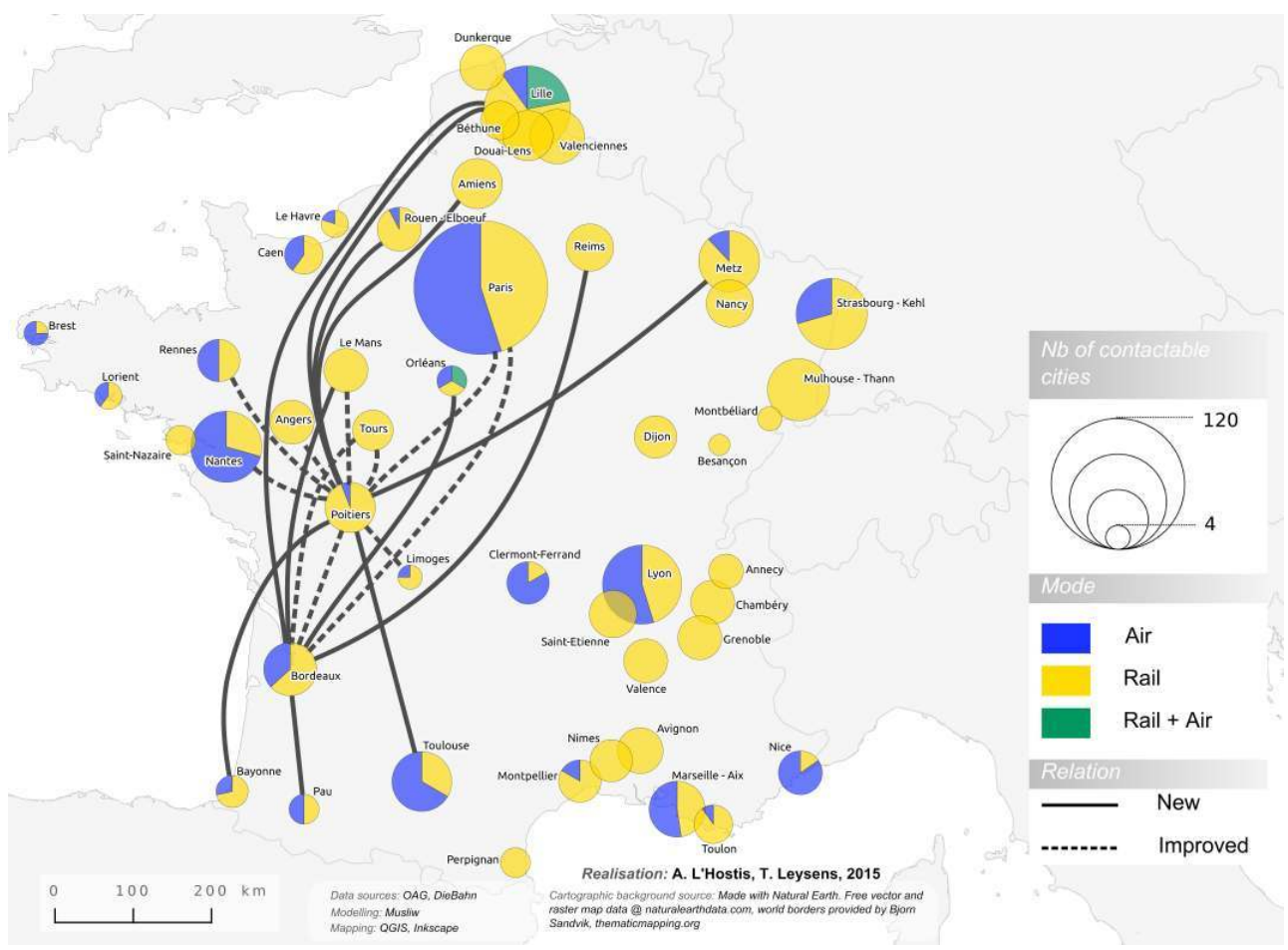
limited spread of this effect to the standard railway network, as in the case of the link between Bordeaux and Orléans, where there is a mix of standard and high-speed infrastructure. Poitiers and Bordeaux improve their links to the high-speed network and its cities, especially to Paris, but also beyond on high-speed rail branches to the north with Lille and Brussels, and to the east with Reims. Despite the bidirectional character of the infrastructure and its services, the benefits to Poitiers and Tours in a southwards direction are much inferior to the improvements to the north for Bordeaux and Poitiers. The contact potential relations are closely associated with high-speed rail infrastructure. 


\section{Conclusion}

The work presented here brings two new sets of contributions, on both the methodological and the empirical side. We also provide some potential directions for future work.

From a methodological point of view, following several contributions within the framework of European spatial planning, this paper presents a new analysis of the interaction between cities and transport, based on the contact potential indicator. In addition, from the perspective of assessing a new transport system, our use of the timetable based approach provides a solution to one limitation of these studies. It is quite easy to build a model of the future state of the transport system in an approach based on minimum times, where there is essentially just one value to be changed on a given link. Things are very different in a timetable approach, where multiple schedules have to be altered in order to reflect the changes in travel times on a single link. We have achieved this by using specially designed tools that represent schedules in a form similar to the timetables that transport operators provide to service users. This approach allows existing services to be modified both on the new line and beyond on the standard network, which is a particularity of the French railway system. It is then possible to model a future transport supply realistically and to import it into a database in order to simulate a future state of transport systems.

3 On the empirical side, this simulation of the impact on contact potential of new transport supply introduces several analytical outcomes, some expected, some unexpected. It is no surprise that the cities that benefit the most from the new line are located directly on the line. However, one of the advantages of our approach was precisely to depart from a direct analysis of infrastructure and to judge the project from its outputs in terms of service. It might have been expected that the new line would also contribute to tangential links in western France, for instance between Bordeaux and Nantes, but this was not observed. New links emerge beyond the new line, but mainly towards the north, beyond Île-de-France, on the northerly and easterly branches of the high-speed rail network.

The new developments emerging from this work are numerous, and were identified at a workshop for practitioners organised in 2013 within the framework of a European research project ${ }^{7}$. Here, we will simply mention the idea that it would be relevant to study the services dedicated to business travellers in and around railway stations, and that the indicator would be very useful for the discussion of metropolitan strategies developed by local actors affected by the new rail line. What strategies could be adopted by smaller cities (like Angoulême or Libourne on the line to Bordeaux) that are in a position to develop metropolitan scale contact potential as a result of the high-speed line? They benefit from a network effect (Laird, Nellthorp and Mackie, 2005) since, though not big enough in themselves to merit such an infrastructure, they have the opportunity to be located on the route of the new high-speed train line. 


\section{BIBLIOGRAPHY}

AGUILERA A. (2008), "Business Travel and Mobile Workers", Transportation Research Part A: Policy and Practice, 42, 8, pp. 1109-1116.

AGUILERA A., LETHIAIS V. (2011), "Transmission des connaissances dans les relations de coopération inter-entreprises: TIC versus Face à face”, Revue d'Économie Régionale \& Urbaine, 2, pp. 269-293.

ALBALATE D., BEL G. (2012), "High-Speed Rail: Lessons for Policy Makers from Experiences Abroad", Public Administration Review, 72, 3, pp. 336-349.

ARMSTRONG J. (1998), “Transport History, 1945-1995 : The Rise of a Topic to Maturity”, Journal of Transport History, 19, 2, pp. 103-121.

BATHELT H., MALMBERG A. \& MASKELL P. (2004), "Clusters and Knowledge: Local Buzz, Global Pipelines and the Process of Knowledge Creation", Progress in Human Geography, 28, 1, pp. 31-56, doi:10.1191/0309132504ph469oa.

BBR (2006), "Integrated Analysis of Transnational and National Territories Based on ESPON Results”, ESPON, http://www.espon.eu/main/Menu_Projects/Menu_ScientificPlatform/ Menu_MapUpdates/accessibility.html.

BEHRENS C., PELS E. (2012), "Intermodal Competition in the London-Paris Passenger Market: High-Speed Rail and Air Transport”, Journal of Urban Economics, 71, 3, pp. 278-288, doi:10.1016/ j.jue.2011.12.005.

BODEN D., MOLOTCH H. (1994), “The Compulsion of Proximity”, in BODEN D., FRIEDLAND R., Nowhere: Space, Time and Modernity, Berkeley, University of California Press, pp. 257-286.

BONNAFOUS A. (1987), "The Regional Impact of the TGV”, Transportation, 14, 2, pp. 127-137, doi:10.1007/BF00837589.

BOZZANI S. (2005), "L'Intermodalité air-fer à grande vitesse au service du rayonnement métropolitain: étude de l'articulation modale à l'aéroport de Roissy-Ch. de Gaulle au départ de Lille", Cahiers scientifiques du Transport, 47, pp. 61-88.

BOZZANI-FRANC S. (2006), Grandes vitesses, métropolisation et organisation des territoires : l'apport de l'intermodalité aéro-ferroviaire à grande vitesse au rayonnement métropolitain, Géographie et Aménagement, Université des Sciences et Technologie de Lille - Lille I, http://tel.archivesouvertes.fr/tel-00294581.

BRÖCKER J., KORZHENEVYCH A. \& SCHÜRMANN C. (2010), “Assessing Spatial Equity and Efficiency Impacts of Transport Infrastructure Projects", Transportation Research Part B: Methodological, Modelling Non-urban Transport Investment and Pricing, 44, 7, pp. 795-811, doi:10.1016/j.trb.2009.12.008.

CAMPOS J., DE RUS G. (2009), “Some Stylized Facts about High-Speed Rail: A Review of HSR Experiences around the World", Transport Policy, 16, 1, pp. 19-28, doi:10.1016/

j.tranpol.2009.02.008. 
CHARDONNEL S. (2001), "La time-geography: les individus dans le temps et l'espace”, Modèles en analyse spatiale, Traité Information Géographique et Aménagement Du Territoire, Série aspects fondamentaux de l"analyse spatiale, Paris, Lavoisier, pp. 129-156.

CONESA, A., L"HOSTIS A. (2013), "Defining Intermodal Accessibility”, Geographical Information and Urban Transport Systems, pp. 53-81.

CONFÉRENCE DES RÉGIONS PÉRIPHÉRIES MARITIMES (2002), Étude sur la construction d'un modèle de développement polycentrique et équilibré du territoire.

DIJST M., DE JONG T. \& VAN ECK J.R. (2002), “Opportunities for Transport Mode Change: An Exploration of a Disaggregated Approach", Environment and Planning B: Planning and Design, 29, 3, pp. 413-430.

DOBRUSZKES F., DEHON C. \& GIVONI M. (2014), “Does European High-Speed Rail Affect the Current Level of Air Services? An EU-Wide Analysis", Transportation Research Part A: Policy and Practice, 69, pp. 461-475, doi:10.1016/j.tra.2014.09.004.

ENGSTRÖM M.-G., SAHLBERG B. (1973), Travel Demand, Transport Systems and Regional Development: Models in Co-Ordinated Planning, Royal University of Lund, Department of Geography, http:// www.getcited.org/pub/101534742.

ERLANDSSON U. (1979), “Contact Potentials in the European System of Cities”, Spatial Inequalities and Regional Development, pp. 93-116.

FARBER S., NEUTENS T., CARRASCO J.-A. \& ROJAS C. (2014), "Social Interaction Potential and the Spatial Distribution of Face-to-Face Social Interactions", Environment and Planning B, http:// www.envplan.com/epb/fulltext/b41/b120034p.pdf.

GALLAUD D., TORRE A. (2005), “Geographical Proximity and the Diffusion of Knowledge”, Rethinking Regional Innovation and Change, Springer, pp. 127-146, http://link.springer.com/ content/pdf/10.1007/0-387-23002-5_7.pdf.

GEURS K.T., VAN WEE B. (2004), “Accessibility Evaluation of Land-Use and Transport Strategies: Review and Research Directions”, Journal of Transport Geography, 12, 2, pp. 127-140, doi:10.1016/ j.jtrangeo.2003.10.005.

GIVONI M. (2006), "Development and Impact of the Modern High-speed Train: A Review”, Transport Reviews, 26, 5, pp. 593-611, doi:10.1080/01441640600589319.

GOTTMANN J. (1970), "Urban Centrality and the Interweaving of Quaternary Activities”, Ekistics, 29, pp. 323-331.

GRUBESIC T., ZOOK M. (2007), “A Ticket to Ride: Evolving Landscapes of Air Travel Accessibility in the United States", Journal of Transport Geography, 15, 6, p. 417.

GUTIERREZ, J. (2001), "Location, Economic Potential and Daily Accessibility: An Analysis of the Accessibility Impact of the High-Speed Line Madrid-Barcelona-French Border", Journal of Transport Geography, 9, 4, pp. 229-242.

HAGERSTRAND T. (1970), “What about People in Regional Science?", Papers of the Regional Science Association, 24, pp. 7-21.

HAGGETT P. (2001), Geography, a Global Synthesis, Harlow, Prentice Hall.

HALBERT L., CICILLE P. \& ROZENBLAT C. (2013), "Quelles métropoles en Europe? Des villes en réseau”, Travaux, 16, DATAR, http://www.datar.gouv.fr/travaux-n-16-quelles-metropoles-eneurope-des-villes-en-reseau-de-ludovic-halbert-patricia-cicille-e. 
HAYNES K.E. (1997), "Labor Markets and Regional Transportation Improvements: The Case of High-Speed Trains An Introduction and Review”, The Annals of Regional Science, 31, 1, pp. 57-76.

HOUÉE M., KLEIN O. (1999), “Le TGV Atlantique et Les Fluctuations de La Mobilité”, in ANDRÉ PÉNY A., WACHTER S. (eds.), Les Vitesses de la ville, edited, La Tour d"Aigues, Éditions de l'Aube, pp. 131-155.

KELLERMAN A. (2012), Daily Spatial Mobilities: Physical and Virtual, Ashgate Publishing Limited.

KLEIN O. (2005), “Temporalités sociales et gestion de la distance à travers les moyens de transport rapides”, Mobilités et Temporalités, http://halshs.archives-ouvertes.fr/halshs-00091072.

KWAN M.-P. (1998), “Space-Time and Integral Measures of Individual Accessibility: A Comparative Analysis Using a Point-Based Framework", Geographical Analysis, 30, pp. 191-216.

KWAN M.-P., MURRAY A.T., O"KELLY M. \& TEIFELSDORF M. (2003.), "Recent Advances in Accessibility Research: Representation, Methodology and Applications”, Journal of Geographical Systems, 5, pp. 129-138.

LAIRD J.J., NELLTHORP J. \& MACKIE P.G. (2005), “Network Effects and Total Economic Impact in Transport Appraisal”, Transport Policy, 12, 6, pp. 537-544.

LE GALÈS P. (2003), Le retour des villes européennes. Sociétés urbaines, mondialisation, gouvernement et gouvernance, Paris, Presses de Sciences Po.

LENNERT M., VAN HAMME G., SMĘTKOWSKI M., PLOSZAJ A., GORZELAK G., KOZAK M. et al. (2010), FOCI: Future Orientation for Cities, Applied Research 2013/1/1, http://hal.archives-ouvertes.fr/ hal-00734406.

LEVINSON D.M. (2012), “Accessibility Impacts of High-Speed Rail”, Journal of Transport Geography, Special Section on Rail Transit Systems and High-speed Rail, 22, pp. 288-291, doi:10.1016/ j.jtrangeo.2012.01.029.

L'HOSTIS A., BAPTISTE H. (2006), “A Transport Network for a City Network in the Nord-Pas-deCalais Region: Linking the Performance of the Public Transport Service with the Perspectives of a Monocentric or a Polycentric Urban System", European Journal of Spatial Development, http:// www.nordregio.se/EJSD/.

LIAN J.I., DENSTADLI J.M. (2004), “Norwegian Business Air Travel-segments and Trends”, Journal of Air Transport Management, 10, 2, pp. 109-118.

LORENTZON S. (2003), "Changes in the Flows and Means of Information Exchange: Business Uses of ICT in Sweden in the 1990s", Journal of Urban Technology, 10, 1, pp. 89-110.

MATHIS P., BOCK E., BUGUELLOU J.-B., COQUIO J., GUIMAS L., L'HOSTIS A., BOZZANI S., et al. (2004), "Transport Services and Networks: Territorial Trends and Basic Supply of Infrastructure for Territorial Cohesion”, ESPON, http://www.espon.eu/mmp/online/website/content/ projects/259/652/index_EN.html.

OFFNER J.-M. (1993), “Les effets structurants du transport: mythe politique, mystification scientifique”, Espace Géographique, 3, pp. 233-242.

ORTEGA E., LÓPEZ E. \& MONZÓN A. (2012), “Territorial Cohesion Impacts of High-Speed Rail at Different Planning Levels", Journal of Transport Geography, Special Section on Theoretical Perspectives on Climate Change Mitigation in Transport, 24 (September), pp. 130-141, doi:10.1016/j.jtrangeo.2011.10.008. 
ROUSSEL P. (2011), “La mobilité à longue distance des Français”, Le Point Sur, 105, La Défense, Commissariat général au développement durable, http://www.developpement-durable.gouv.fr/ La-mobilite-a-longue-distance-des.html.

ROZENBLAT C., CICILLE P. (2003), Les villes européennes, analyse comparative, Paris, La Documentation française/DATAR.

SASSEN S. (1991), The Global City: New York - London - Tokyo, Oxford, Princeton University Press.

SHAW S.-L., FANG Z., LU S. \& TAO R. (2014), "Impacts of High-speed Rail on Railroad Network Accessibility in China", Journal of Transport Geography, Changing Landscapes of Transport and Logistics in China, 40 (October), pp. 112-122, doi:10.1016/j.jtrangeo.2014.03.010.

SIMMEL G. (1903), "The Metropolis and Mental Life”, The Urban Sociology Reader, pp. 23-31.

SIMMEL G. (1997), Simmel on Culture: Selected Writings, SAGE.

SPIEKERMANN K., WEGENER M. (2007), Update of Selected Potential Accessibility Indicators, ESPON, http://www.espon.eu/main/Menu_Projects/Menu_ScientificPlatform/Menu_MapUpdates/ accessibility.html.

SPIEKERMANN K., WEGENER M., KVĚTOŇ V., MARADA M. \& SCHÜRMANN C., BIOSCA O., ULIED A., et al. (2012), Transport Accessibility at Regional/Local Scale and Patterns in Europe, 2013/1/10, Applied Research. ESPON, http://www.espon.eu/main/Menu_Projects/Menu_AppliedResearch/ tracc.html.

TÖRNQVIST G. (1968), "Flows of Information and the Location of Economic Activities", Geografiska Annaler. Series B, Human Geography, 50, 1, pp. 99-107.

TÖRNQVIST G. (1970), Contact Systems and Regional Development, Royal University of Lund, Department of Geography.

TÖRNQVIST G. (1973), Contact Requirements and Travel Facilities: Contact Models of Sweden and Regional Development Alternatives in the Future.

TORRE A. (2009), “Retour sur la notion de proximité géographique”, Géographie, économie, Société, 11,1, pp. 63-74.

VELTZ P. (1997), Mondialisation, Villes et Territoires, PUF.

VIVANT E. (2009), Qu'est-ce que la ville créative?, in DONZELOT J. (éd.), La Ville En Débat, Paris, PUF, http://halshs.archives-ouvertes.fr/halshs-00456178.

WICKHAM, J., VECCHI A. (2009), “The Importance of Business Travel for Industrial Clustersmaking Sense of Nomadic Workers", Geografiska Annaler: Series B, Human Geography, 91, 3, pp. 245-255.

\section{NOTES}

1. We have chosen to tackle the subject via metropolises and global city formation; an alternative would have been to develop our approach, as in another article (L'Hostis and Baptiste, 2006), from the perspective of territorial cohesion; both approaches provide room for discussion of the ideas of continuous or occasional urban co-presence.

2. Interview of the director of Lille-Lesquin airport in 2007.

3. Website: http://oagdata.com.

4. Website: http://www.diebahn.de. 
5. Software developed by Patrick Palmier from CEREMA.

6. Bruxelles is the only non-French city also affected.

7. The COST action 1002 « Accessibility instruments».

\section{ABSTRACTS}

New high-speed rail transport infrastructures produce profound time-space changes that make new activities possible. Our aim is to measure the impact of such changes on potential business or leisure travel between cities.

We develop a contact potential indicator (Törnqvist, 1970) that measures the possibility of making a trip to a distant location within the desirable time-space prism. The indicator is developed in the context of the high-speed rail line between Tours and Bordeaux.

The results demonstrate the possibility of contact from a series of key cities affected by new high-speed rail infrastructure, both before and after project completion. Our analysis shows that Bordeaux benefits greatly from the extension of the rail line: the preferred method of contact to Paris will switch to rail from the current air preference, and several cities that cannot be reached in the current pre-project conditions will become "contactable". Other cities that benefit are Angoulême, Tours and Poitiers.

Les nouvelles infrastructures de transport ferroviaire provoquent de profondes transformations de l'espace-temps qui rendent de nouvelles activités possibles. Notre but est de mesurer les impacts de telles transformations sur le potentiel de déplacement pour motif affaires ou tourisme entre villes.

Nous développons l'indicateur du potentiel de contact (Törnqvist, 1970) qui mesure la possibilité d'effectuer un déplacement vers un lieu distant dans les contraintes du prisme d'espace-temps de la time geography. L'indicateur est mis en œuvre dans le contexte de l'ouverture de la ligne ferroviaire à grande vitesse entre Tours et Bordeaux.

Les résultats démontrent la possibilité de contact entre un ensemble de villes clés affectées par la nouvelle infrastructure de transport rapide, avant et après son ouverture. Notre analyse montre que Bordeaux bénéficie grandement de l'extension de la ligne : le mode le plus favorable pour réaliser le potentiel de contact avec Paris bascule de l'aérien au ferroviaire, et plusieurs villes qui ne pouvaient pas être rejointes dans les conditions précédant la réalisation du projet ferroviaire, deviennent « contactables ». Les autres villes bénéficiaires sont Angoulême, Tours et Poitiers.

\section{INDEX}

Mots-clés: potentiel de contact, train à grande vitesse, ligne ferroviaire à grande vitesse ToursBordeaux

Keywords: contact potential, high-speed train, Tours-Bordeaux high-speed rail line 


\section{AUTHORS}

\section{ALAIN L'HOSTIS}

Université Paris-Est, LVMT (UMR_T 9403), Ecole des Ponts ParisTech, IFSTTAR, UPEMLV, F-77455

Marne la Vallée, France, alain.lhostis@ifsttar.fr

\section{LIU LIU}

Université Paris-Est, LVMT (UMR_T 9403), Ecole des Ponts ParisTech, IFSTTAR, UPEMLV, F-77455 Marne la Vallée, France, liu.liu@enpc.fr

\section{THOMAS LEYSENS}

Université Paris-Est, LVMT (UMR_T 9403), Ecole des Ponts ParisTech, IFSTTAR, UPEMLV, F-77455 Marne la Vallée, France, leysens@enpc.fr 